\title{
Effectiveness of the Use of Stop Motion Animation Learning Media in Understanding Historical Materials at Elementary School
}

\author{
Omi Rohmiyah', Asri Wibawa Sakti'²,* \\ ${ }^{1}$ Departemen Pendidikan Sejarah, Universitas Pendidikan Indonesia. \\ ${ }^{2}$ Departemen Pendidikan Kesejahteraan Keluarga, Universitas Pendidikan Indonesia. \\ *Corresponding author : achiewibawasakti@upi.edu
}

\begin{abstract}
Abstrak: Media pembelajaran adalah faktor keberhasilan dalam proses pembelajaran. Penggunaan media yang menarik mampu membuat siswa lebih fokus dalam memahami materi pelajaran. Tujuan dari kegiatan ini adalah untuk menentukan efektivitas media pembelajaran animasi stop motion dalam memahami materi sejarah bagi siswa sekolah dasar. Penelitian ini menggunakan metode aktivitas subjek tunggal dengan desain pra-tes dan pasca-tes. Mata pelajaran dari penelitian ini adalah sepuluh siswa sekolah dasar kelas enam. Hasil pasca-tes menunjukkan bahwa video animasi stop motion sangat efektif dalam meningkatkan pemahaman siswa tentang materi sejarah. Berdasarkan hasil pre-test dan post-tes menunjukkan peningkatan yang signifikan dalam pemahaman siswa tentang materi sejarah. Hasil penelitian ini menunjukkan bahwa penggunaan media animasi stop motion sangat efektif dalam meningkatkan pemahaman siswa kelas VI SD dalam materi sejarah tentang momen proklamasi. Hal ini terjadi karena stop motion merupakan media yang menarik dengan penjelasan sederhana yang membuat materi pelajaran lebih mudah dipahami.
\end{abstract}

Kata kunci: sekolah dasar, sejarah, pembelajaran, media, stop motion.

\begin{abstract}
Learning media is a success factor in the learning process. The use of interesting media is able to make students more focused in understanding the subject matter. The purpose of this study was to determine the effectiveness of stop motion animation learning media in understanding historical material for elementary school students. This study used a single subject activity method with a pre-test and post-test design. The subjects of this study were ten sixth grade elementary school students. Based on the post-test results, it shows that stop motion animation videos are very effective in increasing students' understanding of historical material. Based on the results of the pre-test and post-test showed a significant increase in students' understanding of historical material. The results of this study showed that the use of stop motion animation media was very effective in improving the understanding of class VI student's elementary school in historical material about the proclamation moments. This happens because stop motion is an interesting medium with simple explanations that make the subject matter easier to understand.
\end{abstract}

Keywords: elementary school, historical, learning, media, stop motion. 


\section{Introduction}

The development of information technology affects various lives is no exception in the world of education. This encourages various educational institutions to utilize e-learning systems to increase the effectiveness and flexibility of learning (Wibowo, 2014). One of the e-learning that can be used is to use stop motion animation. Stop motion animation is an audiovisual media that can be used as a learning medium. Stop motion is a traditional animation creation method, where this method uses photography techniques to take object images (Wijayanto, 2014). This medium is in the form of a series of images made like life to help students in understanding the concept of the material studied (Kusemawati et al. , 2018).

In the 2013 curriculum of learning using a scientific approach, the scientific approach is a scientific or scientific approach. The learning process must touch three realms, namely, attitude, skill, and knowledge. Learning with scientific shortness is learning consisting of observing activities (to identify problems that want to be known), formulate questions and formulate hypotheses, collect data information with various techniques, process analyse data information and draw conclusions and communicate results consisting of conclusions and also other findings outside the formulation of problems (Permatasari, 2014). Therefore, the teacher has a main role as a facilitator, being a benchmark for the success of understanding the subject matter by students. This means allowing students to determine learning needs and objectives and utilize various sources (Rahmawati \& Suryadi, 2019).

Historical science education explains a progress in the meaning of state values, knowledge, and skills in history that are arranged to give influence and encourage the formation of the past learning process. History will continue to exist as long as people are still there and alive, so that people will not be separated from the word history (Yansaputra \& Pangestika, 2020).

The development of technology today in various fields affects human life at this time including the world of education. The role of the media is very important. Learning media in the form of machines (technology) is seen as a science application that occupies a strategic position in simplifying and smoothing the learning process, the range of learning also becomes wider and faster (Miftah, 2013).

Media in the narrow sense is a component of materials and tools in a learning system. In a broad sense media means maximum utilization of all the components of the system and the above learning resources to achieve certain learning goals (Miftah, 2013). In line with that (Abdillah et al., 2017) Learning Media is a tool of the learning and teaching process. 
Everything that can be used to stimulate the mind, feelings, abilities or skills of learners and attention so as to encourage the learning process.

There are several functions of learning media, including increasing learning motivation and student attention, increasing the effectiveness and efficiency of information delivery, and the ease of material to digest and more effective so that it is not easily forgotten by students (Rahmawati, 2013).

Based on the description above, this activity aims to measure the effectiveness of the use of stop motion animation in understanding historical material in elementary school. The material used based on the core competencies and basic competencies of Social Sciences Elementary in Class VI point 3.4 understands the meaning of the proclamation of independence, efforts to maintain independence and efforts to develop a prosperous national life.

\section{Methods}

\subsection{Learning using Stop motion}

Learning is carried out aimed at the achievement of certain competencies in each student, through this learning will appear learning activities. Learning that gives rise to learning activities is a study designed in such a way that it can awaken and improve various competencies that exist in students as well as interests, motivations, learning outcomes and so on. The success of teachers in improving student competence depends largely on the smooth communication interaction between teachers and their students (Rahmadani, 2017).

Stop motion animation is an audio-visual media that can be used as a learning medium. Stop motion is a traditional animation creation method, where this method uses photography techniques to take object images (Wijayanto, 2014). This media is in the form of a series of images made like life to help students in understanding the concepts of the material studied. Creating stop motion animation is relatively easy. Someone who wants to create a stop motion animation does not require any special skills. Stop motion can be made with a digital camera, tripod, and computer-specific programs that can be used to move existing images. Even now using a smartphone can already create stop motion animations because the supporting application is already in the play store (Kusemawati et al. , 2018). 


\subsection{Historical education for elementary education}

Historical learning is often considered a subject that focuses on the knowledge of the past, this then assumes that studying history has no effect and is not related to present or future life. Not infrequently also students who think that history subjects are ancient, so do not consider history subjects are important to learn (Apriana, 2016).

Taufik Abdullah gave an assessment, that the pedagogical strategy of Indonesian History is very weak. Historical education in schools still dwells on chronicle approaches and tends to require children to memorize events. Students are not accustomed to interpreting an event in order to understand the dynamics of a change (Alfian, 2011). Historical Education for elementary education (elementary and junior high) was developed as a foundation to build a better generation of the nation. Now they are the majority in Indonesia so it is fitting that this nation hangs the future in their hands (Hasan, 2019).

To prepare the younger generation to be able to face 21 st century life full of changes as stated above, specifically historical education needs to develop three historical education competencies related to change, namely:

(i) Competence to know and understand the changes that have occurred, are and will occur in the circle of life of him, society, nation and mankind.

(ii) Competence adapts change in enriching the life of himself, society, the nation as a human being who uses technology instead of technology.

(iii) Competence determines change for the future life of itself, society, nation and humanity as the master of technology and the happiness of human life. In these three historical educational competencies the three dimensions of historical time are covered. Knowing and understanding the changes that occur is the dimension of past and present time (Hasan, 2019).

Historical Education has the ability to develop the complement of learners in participating in determining the color, dimensions, aspects and direction of change that is taking place and for the future. The ability to adapt is the ability to determine colors, dimensions, aspects and direction of change for present life. This ability is able to maintain the originality of the personality of the nation listed in Pancasila. Adapting competence requires the ability to analyze, evaluate, and find various positive alternatives to the influence of technological progress on Pancasila values. Historical education is able to provide past experiences into 
present experiences, learn from past experiences into the attitudes and wisdom of present life, and build present experiences as the basis for the sustainability of future lives (Hasan, 2019).

The type of activity method used is quantitative activity using the pre-experimental design method (one group pre-test-post-test). We were fully involved in data collection. The data collection technique used in this study was an online questionnaire method via google form to find out the students' views on the material "Effectiveness of The Use of Stop Motion Animation earning Media in Understanding Historical Material in Elementary School". The population in this study were 27 students of class VI Elementary School. The sample used in this study was 10 students of class VI Elementary School via google form. This activity was conducted in 2 stages, divided into 2 sessions, namely the first pre-test before the material was presented and the second post-test after the material about the proclamation of independence using stop motion video was presented to determine the extent of understanding of the material. The instrument designed is in the form of a two-choice Likert scale (yes and no). The data obtained will be processed and then compared until finally the results will be concluded.

\section{Result and Discussion}

\subsection{Demography}

This activity was conducted at Elementary School at SDN Buaranjati II Tangerang, Indonesia. Fig. 1 show a selected class to contribute as the activity sample from $6^{\text {th }}$ grade. The population in this study amounted to 27 students with the sample for this study amounted to 10 students. Samples were taken based on student activity in online learning activities taking place. Demographic data in this study is the gender of the sample. Based on the results of demographic data obtained by gender, $24.4 \%$ (4 students) of students were male and $75.6 \%$ (6 students) were female.

Based on it, no one has special problems so they don't mind taking part in this activity. Before the learning activity, we had a little discuss with the students. We saw that five male and female students have a hobby of drawing, and; two of them very often watch videos on various social media. 


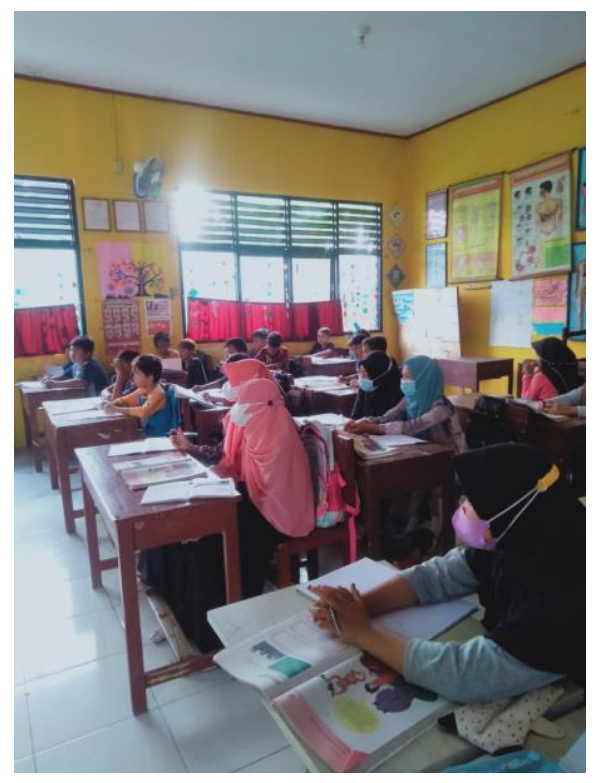

Fig. 1. Face-to-face learning is limited.

\subsection{Pre-test and post-test results}

Learning activities at elementary school are carried out online. Tools and media used in learning through WhatsApp and google form as shown in Fig. 2. In addition to introducing the two applications, it was distributed online questionnaires via google forms which were distributed to students through the WhatsApp application to find out the extent of understanding the historical materials for the moment of the proclamation.
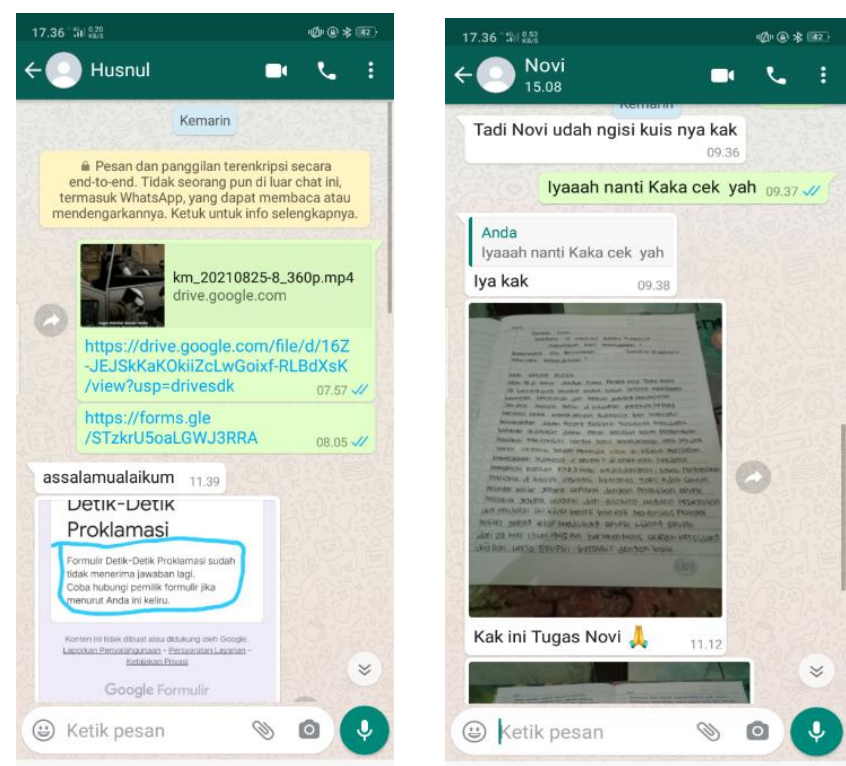

Fig. 2. Spread of animated videos and quizzes.

Volume 3, Nomor 1, Maret 2022| 34

Effectiveness of the Use of Stop Motion Animation Learning Media in Understanding Historical Materials at Elementary School. 
Jurnal Abdimas Kartika Wijayakusuma ISSN 2716-3512 (Online) ISSN 2721-0367 (Print)
This work is licensed under a Creative Commons Attribution-ShareAlike 4.0 International License.

Table 1 describes the questions that have pre-test and post-test proposed. The first questionnaire that was made was a pre-test questionnaire. The making of this questionnaire was distributed to students of class VI elementary school, which aims to find out how far the historical materials for moments proclamation is by filling out 10 questions. After that, the activityer will provide historical material through with stop motion animation. After explaining the material, the activityer redistributed the questionnaire with the same question, namely in the form of a post-test to the students with the aim of understanding the historical material for the moment of the proclamation.

Table 1. Students' pre-test and post-test results.

\begin{tabular}{|c|l|c|c|c|}
\hline No & \multicolumn{1}{|c|}{ Question } & Pre-test & Post-test & Gain \\
\hline 1 & Is the picture above Ir. Soekarno? & $80 \%$ & $95 \%$ & $15 \%$ \\
\hline 2 & Is Ir. Soekarno the father of proclamation? & $85 \%$ & $90 \%$ & $5 \%$ \\
\hline 3 & $\begin{array}{l}\text { Was the red and white flag tailored by Ms. } \\
\text { Femtowatt? }\end{array}$ & $70 \%$ & $95 \%$ & $25 \%$ \\
\hline 4 & What the picture above is Moh. Hatta? & $75 \%$ & $95 \%$ & $20 \%$ \\
\hline 5 & $\begin{array}{l}\text { Was the text of the proclamation typed by Sayuti } \\
\text { Melik? }\end{array}$ & $70 \%$ & $90 \%$ & $20 \%$ \\
\hline 6 & Did Independence Day happen on August 15, 1945? & $95 \%$ & $100 \%$ & $5 \%$ \\
\hline 7 & $\begin{array}{l}\text { Was it before the independence of the Indonesian } \\
\text { nation divided into young and old? }\end{array}$ & $80 \%$ & $95 \%$ & $15 \%$ \\
\hline 8 & $\begin{array}{l}\text { Does Independence Day mean so much to the people } \\
\text { of Indonesia? }\end{array}$ & $100 \%$ & $100 \%$ & $0 \%$ \\
\hline 9 & Is it to fill our freedom by lazy learning? & $100 \%$ & $100 \%$ & $0 \%$ \\
\hline 10 & Is Indonesia really free now? & $100 \%$ & $5 \%$ \\
\hline
\end{tabular}

\subsection{Result discussion}

(i) For question number one the result increased by $15 \%$ when the material on the meaning of Soekarno.

(ii) For question number two the results increased by $5 \%$ when the understanding of who Soekarno. 
(iii) For question number three the result increased the most among other numbers by $25 \%$, presented material of who Fatmawati.

(iv) For question number four the results increased by $20 \%$ after being given the meaning of Hatta.

(v) For question number five the results increased by $20 \%$ when the material on the meaning who Sayuti Melik.

(vi) For question number six the result is quite increased by $5 \%$ after given the meaning of Independence Day.

(vii) For question number seven the result increased by $15 \%$ after given the meaning of moments of Independence Day.

(viii) For question number eight the results increased by $0 \%$ when the given opinion about significant of Independence Day.

(ix) For question number nine the results increased by $0 \%$ after being given the example of significant of Independence Day.

(x) For question number ten the result increased by $5 \%$ when the given of moment the independence day.

From the graph shows that students' knowledge of historical facts about the moments of the proclamation tends to increase. It can be seen with an increasing percentage from the posttest to the pre-test. This media is in the form of a series of images made like life to help students in understanding the concepts of the material studied (Kusemawati et al., 2018).

\section{Conclusion}

The results of this study showed that the use of stop motion animation media was very effective in improving the understanding of class VI student's elementary school in historical material about the proclamation moments. We hope that this activity will result in more new studies on learning media for elementary students in particular for historical materials.

\section{Acknowledgement}

We acknowledged Bangdos, Universitas Pendidikan Indonesia. We thank to Nyai Santi, S.Pd and H. Romli, S.Pd from Elementary School at Buaranjati II, Tanggerang City, Indonesia. This study is a part of community service (Program: KKN Thematic Literacy 2021 (August-Sept 2021 Kelompok 24) Institute of Activity and Community Service (LPPM), Universitas Pendidikan Indonesia. We also thank to The Office of Journals and Publications, Universitas 
Pendidikan Indonesia. We thank to Nissa Nur Azizah, Dwi Fitria Al Husaeni, Dr.Eng. Asep Bayu Dani Nandiyanto, S.T., M.Eng., Muktiarni, S.Pd., M.Pd., and Rina Maryanti, S.Pd., M.Pd.

\section{References}

Abdillah, R., Joyoatmojo, S., and Noviani, L. 2017. Pemanfaatan blog sebagai media pembelajaran dalam meningkatkan prestasi belajar siswa. Jurnal Pendidikan Bisnis dan Ekonomi, 3(1), 1-21.

Alfian, M. 2011. Pendidikan sejarah dan permasalahan yang dihadapi. Khazanah Pendidikan, $3(2), 1-8$.

Apriana, A. 2016. Penggunaan Media Stopmotion untuk Menumbuhkan Motivasi Belajar Siswa dalam Pembelajaran Sejarah. Skripsi Sarjana Tidak Diterbitkan. Departemen Pendidikan Sejarah Universitas Pendidikan Indonesia.

Hasan, S. H. 2019. Pendidikan sejarah untuk kehidupan abad ke-21. Jurnal Pendidik dan Peneliti Sejarah, 2(2), 61-72.

Kusemawati, I., Yeni, L. F., and Titin, T. 2018. Kelayakan media animasi stop motion pada materi jamur kelas X SMA. Jurnal Pendidikan dan Pembelajaran Khatulistiwa, 7(7), 18.

Miftah, M. 2013. Fungsi dan peran media pembelajaran sebagai upaya peningkatan klemampuan belajar siswa. Jurnal Teknologi Pendidikan, 1(2), 95-105.

Permatasari, E. A. 2014. Implementasi pendekatan saintifik dalam kurikulum 2013 pada pembelajaran sejarah. Indonesian Journal of History Education, 3(1), 11-16.

Rahmadani, F. 2017. Pengaruh Penggunaan Media Animasi Stop Motion Berdasarkan Tingkat Motivasi Terhadap Hasil Belajar Siswa dalam Pembelajaran Seni Rupa di MtsN Matur. Skripsi Prod;I Pendidikan Seni Rupa;. Universitas Negeri Padang.

Wibowo, H. S. 2014. Efektivitas pembelajaran sejarah dengan menggunakan model pembelajaran e-learning. Indonesian Journal of History Education, 3(1), 6-10.

Yansaputra, G. \& Pangestika, R. R. 2020. Pengembangan media stopmotion berbantuan stroytelling pada pembelajaran IPS SD. Jurnal Pendidikan and Artikel Pendidikan,12(2), 95-104. 